\title{
Pengaruh Kadar Vitamin D Plasma terhadap Derajat Kekerapan Asma pada Anak
}

Theresia Umboh, Ganung Harsono, Diah Lintang Kawuryan

Bagian Ilmu Kesehatan Anak Fakultas Kedokteran Universitas Sebelas Maret/RSUD Dr. Moewardi, Surakarta

Latar belakang. Dampak vitamin D sebagai immunomodulator dan anti-inflamasi pada penderita asma dapat menjadi faktor proteksi yang baik, Dalam berbagai penelitian, prevalensi defisiensi vitamin D di Indonesia cukup tinggi. Oleh karena itu, perlu diteliti kadar vitamin D plasma dalam hubungannya dengan derajat kekerapan pada asma, sebagai pertimbangan pemberian terapi suportif pada pasien anak dengan asma. Tujuan. Menganalisis pengaruh kadar vitamin D terhadap derajat kekerapan pada asma anak di RSUD Dr. Moewardi Surakarta.

Metode. Studi cross sectional terhadap pasien anak dengan asma bronkial berusia 6-18 tahun yang datang ke poliklinik anak di RSUD Dr. Moewardi, Surakarta. K Kadar 25(OH)D dalam darah diperiksa dan dianalisis korelasinya dengan derajat kekerapan asma menggunakan korelasi Spearman, dengan nilai signifikan bila $\mathrm{p}<0,05$.

Hasil. Tigapuluh tujuh subjek penelitian, rata-rata usia 10-11 tahun, 17 memiliki kadar 25(OH)D cukup (46\%), dan 20 (54\%) mengalami defisiensi. Kadar vitamin D berkorelasi lemah dengan derajat kekerapan asma ( $r=0,221, p=0,594)$, sedangkan faktor risiko pencetus asma berkorelasi kuat $(\mathrm{r}=0,776)$ serta riwayat alergi dalam keluarga menunjukkan hasil korelasi moderat dan signifikan $(\mathrm{r}=0.455, \mathrm{p}=0,022)$ dengan derajat kekerapan asma.

Kesimpulan. Kadar vitamin D plasma yang rendah memiliki korelasi lemah terhadap derajat kekerapan asma yang lebih tinggi pada anak. Sari Pediatri 2022;23(5):313-7

Kata kunci: asma, vitamin D, derajat kekerapan asma, insufisiensi vitamin D, 25(OH)D total

\section{The Impact of the Plasma Vitamin D Level on the Asthma Severity in Children}

Theresia Umboh, Ganung Harsono, Diah Lintang Kawuryan

Background. Vitamin D was known for its ability as an immunomodulator and an anti-inflammatory supplement, whereas in asthmatic patients it can be a beneficial protecting factor. In several kinds of researches, Indonesia showed a high prevalence of vitamin D insufficiency cases, therefore research were needed to assess the plasma vitamin D level on asthmatic children to see its correlation with the degree of severity; and whether a supportive therapy was needed to treat the asthmatic patients in the future.

Objective. Analyzing the impact of vitamin D level on the degree of severity in asthmatic children at Dr. Moewardi Hospital, Surakarta. Methods. A cross sectional study was done on children with bronchial asthma, aging 6 to 18 years old, who came to the pediatric outpatient care at Dr. Moewardi Hospital, Surakarta. We assessed the $25(\mathrm{OH}) \mathrm{D}$ level in plasma, correlating with Spearman correlation test, and with the significant score of $\mathrm{p}<0.05$.

Result. Of the 37 patients, with 10-11 years old in average, 17 of them (46\%) had a sufficient 25(OH)D level, and 20 (54\%) was noted to be insufficient. The plasma vitamin $\mathrm{D}$ level was weakly correlated with the asthma severity $(\mathrm{r}=0.221, \mathrm{p}=0.594)$, while the triggering factors were strongly correlated $(\mathrm{r}=0.776)$, and the family history was also showing a moderate and significant correlation $\mathrm{r}=0.455, \mathrm{p}=0.022$ ).

Conclusion. The low plasma vitamin D level was weakly correlated with the higher asthma severity in children. Sari Pediatri 2022;23(5):313-7

Keywords: asthma, vitamin D, asthma severity, vitamin D insufficiency, 25(OH)D total

Alamat korespondensi: Theresia Umboh. Departemen Ilmu Kesehatan Anak Fakultas Kedokteran UNS, gedung Anggrek 4. Jl. Kolonel Sutarto No.132, Jebres, Kec. Jebres, Kota Surakarta, Jawa Tengah 57126. Email: theresia.umboh@yahoo.com 
A sma adalah penyakit kronis yang paling sering terjadi pada anak. Berdasarkan hasil Riset Kesehatan Dasar (RISKESDAS) tahun 2018, prevalensi penderita asma berusia 5-14 tahun adalah 1,9\%. Berdasarkan jumlah populasi tersebut, proporsi angka kekambuhan mencapai $50,1 \%{ }^{1}$. Berbagai faktor risiko telah diketahui dapat memicu terjadinya serangan asma, termasuk berat ringannya serangan asma yang dialami, di antaranya adalah jenis kelamin, usia, atopi, lingkungan dan polusi udara, ras, infeksi saluran napas.

Klasifikasi pada derajat kekerapan asma anak dapat dinilai pada kunjungan awal pasien, yaitu berdasarkan Pedoman Nasional Asma Anak (PNAA) tahun 2015. Klasifikasi tersebut terdiri atas, asma intermiten yaitu episode gejala asma kurang dari 6 kali per tahun atau jarak antar gejala lebih dari sama dengan 6 minggu; asma persisten ringan yaitu apabila episode gejala asma lebih dari 1 kali per bulan, kurang dari 1 kali per minggu; asma persisten sedang yaitu episode gejala asma lebih dari 1 kali per minggu, tetapi tidak setiap hari; dan asma persisten berat yaitu bila episode gejala asma terjadi setiap hari. ${ }^{2}$

Vitamin D termasuk salah satu yang telah ditelaah berperan pada kekebalan tubuh, terutama dalam regulasi tubuh terhadap respon inflamasi. ${ }^{3}$

Vitamin D, terutama pada penderita asma, dapat berperan sebagai imunomodulator dengan membantu regulasi transkripsi gen yang bekerja dalam proses inflamasi dan imunomodulasi, pada epitel saluran pernapasan. Vitamin D mensupresi sitokin proinflamasi, seperti IL-7, dan IL-13, dan merangsang pembentukan sitokin anti inflamasi seperti IL-10. ${ }^{4}$ Pada sel $\mathrm{T}$, vitamin $\mathrm{D}$ berperan dalam menurunkan produksi IL-2, IL-17, dan interferon (IFN)- Y. Dengan demikian, vitamin $\mathrm{D}$ menurunkan aktivitas sitotoksik dan proliferasi dari sel CD4 dan CD8. Vitamin D juga berperan dalam mencegah proliferasi sel B, diferensiasi sel plasma, dan menekan produksi immunoglobulin (Ig). ${ }^{5}$ Berdasarkan berbagai fungsi di atas, dapat diambil kesimpulan bahwa Vitamin D secara tidak langsung dapat menghambat proses remodeling, memengaruhi kontraktilitas dan pertumbuhan sel saluran respiratori, serta menghambat proliferasi sel-sel pada saluran pernapasan anak penderita asma. ${ }^{6}$

Acuan yang digunakan untuk menilai kadar vitamin D plasma terutama di Indonesia, berdasarkan Panduan Praktik Klinis Ikatan Dokter Anak Indonesia tentang Vitamin D tahun 2018, yaitu kadar 25-hidroksi vitamin $\mathrm{D}(25(\mathrm{OH}) \mathrm{D} 3)$ adalah normal=31-100 ng/ $\mathrm{mL}$, insufisiensi $=21-29 \mathrm{ng} / \mathrm{mL}$, defisiensi $=<20 \mathrm{ng} /$ $\mathrm{mL}$, defisiensi berat $=<5 \mathrm{ng} / \mathrm{mL} .^{7}$

Pada penelitian oleh South East Asian Nutrition Surveys (SEANUTS) yang diadakan pada tahun 20102011 ditemukan bahwa angka insufisiensi vitamin D pada negara Asia Tenggara termasuk Indonesia masih tinggi, walaupun telah mendapatkan paparan sinar matahari yang cukup. Hal ini dapat disebabkan oleh beberapa faktor, termasuk faktor budaya, seperti pemakaian pakaian yang tertutup dan kurang aktivitas di bawah sinar matahari seiring dengan pertambahan usia dan juga asupan nutrisi kaya vitamin D yang kurang. ${ }^{8}$

Tujuan penelitian ini adalah untuk membandingkan dan menganalisis pengaruh kadar vitamin D terhadap derajat kekerapan pada asma anak di RSUD Dr. Moewardi Surakarta, dan diharapkan dapat menjadi rekomendasi bagi petugas kesehatan untuk pemberian suplementasi vitamin D pada pasien yang menderita asma.

\section{Metode}

Rancangan penelitian ini adalah deskriptif analitik dengan desain cross sectional. Pengambilan subjek penelitian dilakukan secara consecutive sampling dari data rekam medis, anamnesis dan pengambilan sampel $25(\mathrm{OH}) \mathrm{D}$ total plasma terhadap pasien asma berusia 6-18 tahun di Poliklinik Anak RSUD Dr. Moewardi Surakarta, mulai November 2020-April 2021. Kriteria inklusi adalah anak yang terdiagnosis asma bronkial berdasarkan riwayat rekam medis maupun diagnosa dokter dan berusia 6-18 tahun. Lembar persetujuan keikutsertaan penelitian ditandatangani orang tua/ wali (informed consent). Kriteria eksklusi adalah pasien yang telah terdiagnosis dengan insufisiensi atau defisiensi vitamin $\mathrm{D}$ sebelumnya, dan pasien yang memiliki penyakit penyerta gagal ginjal kronik, kelainan metabolik, malabsorpsi, kolestasis, dan Rickets refrakter. Penelitian ini telah memperoleh kelaikan etik dari Medical and Health Research Ethics Committee (MHREC) Fakultas Kedokteran Universitas Sebelas Maret, Surakarta.

Dilakukan pengambilan data pada saat pasien berkunjung ke poliklinik anak, orang tua dijelaskan mengenai tujuan dan prosedur penelitian, lalu 
Theresia Umboh dkk: Pengaruh kadar vitamin D plasma terhadap derajat kekerapan asma

menandatangani informed consent. Data yang diambil melalui anamnesis meliputi jenis kelamin, umur, riwayat alergi dalam keluarga, dan apakah pasien memiliki faktor pencetus asma di lingkungan rumah; seperti paparan terhadap asap rokok, hewan peliharaan, paparan terhadap polusi udara. Data mengenai diagnosis dan derajat kekerapan asma diambil dari rekam medis. Anamnesis dan pengambilan data dilakukan oleh peneliti.

Data yang diambil tersebut dimasukkan ke dalam program perangkat lunak SPSS ${ }^{\circledast} 22$. Analisis bivariat menggunakan ANOVA dan akan diuji dengan uji korelasi Spearman, untuk mendapatkan nilai $\mathrm{p}<0,05$. Untuk mencari hubungan antara kadar vitamin D dengan asma anak dilakukan uji $\mathrm{T}$ tidak berpasangan.

\section{Hasil}

Subyek penelitian didapatkan 37 pasien dengan asma bronkial yang memenuhi kriteria inklusi. Karakteristik sampel dari penelitian ini tertera pada Tabel 1. Dari 37 sampel tersebut didapatkan anak dengan asma, dengan jenis kelamin terdistribusi rata dan rata-rata usia 10-11 tahun.

Pada Tabel 2 tertera bahwa dari jumlah sampel yang diambil, derajat kekerapan asma berkorelasi lemah dan tidak signifikan terhadap kadar vitamin D pasien. Korelasi moderat dan signifikan didapatkan pada variabel perancu riwayat alergi dalam keluarga, dan korelasi kuat didapatkan pada faktor risiko derajat kekerapan asma pada anak.

\section{Pembahasan}

Pada beberapa penelitian terdahulu, banyak faktor disebutkan sebagai penyebab rendahnya kadar vitamin $\mathrm{D}$ dalam darah penderita asma. Faktor penyebab tersebut di antaranya adalah riwayat kadar vitamin $\mathrm{D}$ ibu yang rendah pada masa antenatal; riwayat alergi yang diturunkan; penggunaan obat-obatan steroid yang menurunkan penyerapan vitamin $\mathrm{D}$; serta rendahnya asupan vitamin $\mathrm{D}$ sehari-hari.

Berdasarkan studi Adams SN dkk ${ }^{9}$ dilaporkan bahwa pada ibu dengan kadar kalsidiol di bawah 75 $\mathrm{nmol} / \mathrm{L}$, berisiko lima kali lebih tinggi untuk janinnya akan menderita asma, setidaknya pada usia paling
Tabel 1. Karakteristik data penelitian

\begin{tabular}{lc}
\hline Variabel & Hasil \\
\hline Jenis kelamin (\%) & $19(51,4)$ \\
Laki-laki & $18(48,6)$ \\
Perempuan & $10,84+3,50$ \\
Usia & \\
Kadar vitamin D serum (\%, ng/dL) & $17(45,9)$ \\
$\quad$ Cukup & $20(54,1)$ \\
$\quad$ Defisiensi & \\
Alergi dalam keluarga (\%) & $12(32,4)$ \\
Tidak ada & $25(67,6)$ \\
Ada & \\
Faktor risiko yang memengaruhi & \\
derajat kekerapan asma (\%) & $19(51,4)$ \\
Ada & $18(48,6)$ \\
Tidak ada & \\
Derajat kekerapan asma (\%) & $19(51,4)$ \\
Intermittent & $13(35,1)$ \\
Persisten ringan & $4(10,8)$ \\
Persisten sedang & $1(2,7)$ \\
Persisten berat & \\
\hline
\end{tabular}

lambat sembilan tahun. Rendahnya kadar $25(\mathrm{OH})$ $\mathrm{D}$ in utero dan era post-natal dapat berpengaruh pada pertumbuhan janin, termasuk memengaruhi pertumbuhan paru-paru dan saluran pernapasan, dan menjadi faktor penting dalam potensi timbulnya asma di kemudian hari. Ibu dengan defisiensi vitamin D saat mengandung akan menyebabkan mayoritas pada anakanak yang lahir mengalami serangan mengi ataupun manifestasi alergi pada saluran pernapasan lainnya, bahkan pada usia sebelum tiga tahun. ${ }^{9}$ Sebaliknya, ibu yang mendapat asupan vitamin D lebih tinggi pada saat kehamilan berhubungan dengan risiko reaksi alergi yang rendah pada anak hingga anak tersebut berusia lima tahun.

Dalam hubungannya dengan penggunaan obatobatan, terutama dalam terapi asma. Pada tahun 2017, Kang $\mathrm{dkk}^{10}$ meneliti hubungan antara kadar vitamin $\mathrm{D}$ dalam serum anak penderita asma dengan jumlah serangan asma yang dialami. Kang $\mathrm{dkk}^{10}$ mengevaluasi efek terapi kombinasi budesonide dan albuterol, dibandingkan dengan penderita yang diberikan terapi yang sama, tetapi mendapatkan suplementasi vitamin D. Dalam penelitian tersebut dan beberapa penelitian lainnya ditunjukkan bahwa kadar vitamin D dalam serum anak penderita asma secara umum lebih rendah 
Theresia Umboh dkk: Pengaruh kadar vitamin D plasma terhadap derajat kekerapan asma

Tabel 2. Hubungan karakteristik subyek dengan derajat kekerapan asma

\begin{tabular}{|c|c|c|c|c|c|c|}
\hline \multirow[t]{2}{*}{ Variabel } & \multicolumn{4}{|c|}{ Derajat kekerapan asma } & \multirow[t]{2}{*}{$\mathrm{r}$} & \multirow[t]{2}{*}{$\mathrm{p}$} \\
\hline & $\begin{array}{c}\text { Intermittent } \\
(\mathrm{n}=19)\end{array}$ & $\begin{array}{l}\text { persisten ringan } \\
(\mathrm{n}=13)\end{array}$ & $\begin{array}{c}\text { persisten sedang } \\
(\mathrm{n}=4)\end{array}$ & $\begin{array}{l}\text { persisten berat } \\
(\mathrm{n}=1)\end{array}$ & & \\
\hline Jenis kelamin (\%) & & & & & 0,407 & 0,062 \\
\hline Laki-laki & $6(16,2)$ & $10(27)$ & $2(5,4)$ & $1(2,7)$ & & \\
\hline Perempuan & $13(35,1)$ & $3(8,1)$ & $2(5,4)$ & $0(0,0)$ & & \\
\hline Usia & $11,37+3,93$ & $9,31+2,69$ & $13,50+1,91$ & $10,00+$ & $-0,065$ & 0,701 \\
\hline Alergi dalam keluarga ( & & & & & 0,455 & $0,022^{*}$ \\
\hline Tidak ada & $5(13,5)$ & $3(8,1)$ & $4(10,8)$ & $0(0,0)$ & & \\
\hline Ada & $14(37,8)$ & $10(27)$ & $0(0)$ & $1(2,7)$ & & \\
\hline Kadar vitamin D (\%) & & & & & 0,221 & 0,594 \\
\hline Cukup & $9(2,7)$ & $6(5,4)$ & $1(0,0)$ & $1(2,7)$ & & \\
\hline Defisiensi & $10(48,6)$ & $7(29)$ & $3(10,8)$ & $0(0)$ & & \\
\hline Faktor risiko (\%) & & & & & $0,776^{*}$ & 0,170 \\
\hline Ada & $9(24,3)$ & 7 (19) & $2(5,4)$ & $1(2,7)$ & & \\
\hline Tidak ada & $10(27)$ & $6(16)$ & $2(5,4)$ & $0(0,0)$ & & \\
\hline
\end{tabular}

daripada anak yang tidak memiliki penyakit asma. ${ }^{6,10}$ Pada hasil penelitian tersebut, setelah enam bulan pemberian suplementasi vitamin $\mathrm{D}$, didapatkan rekurensi serangan asma dan tingkat kontrol lebih tinggi pada anak yang mendapatkan suplementasi vitamin D dibandingkan dengan yang hanya mendapatkan terapi kontrol untuk asma saja. Hal ini juga terlihat secara histopatologis, kandungan IL-2 dan IFN- pada anak yang mendapat suplementasi vitamin D terbukti lebih rendah. ${ }^{10}$

Selain faktor tersebut di atas, faktor terapi imunosupresan juga berpengaruh pada kadar vitamin D dalam serum. Obat-obatan imunosupresan, seperti golongan kortikosteroid sering digunakan dalam jangka panjang, pada tatalaksana penyakit-penyakit keganasan, autoimun, alergi, dan bahkan pada penyakit asma sendiri. ${ }^{11-13}$ Berdasarkan penelitian yang dilakukan oleh Searing dkk, ${ }^{14}$ penggunaan obat-obatan kortikosteroid dapat menyebabkan penurunan kadar vitamin D serum yang berakibat pada peningkatan kerentanan sel-sel saluran pernapasan sehingga serangan asma pun akan kerap berulang.

Pada meta analisis oleh Jat dan Khairwa ${ }^{4}$ dirangkum beberapa penelitian yang melibatkan beberapa negara dengan paparan sinar matahari yang beragam. Meta analisis tersebut membandingkan paparan sinar matahari dengan insidensi asma dan kadar vitamin $\mathrm{D}$ pada serum anak. Pada studi meta-analisis disebutkan bahwa dari 23 studi cross-sectional yang diteliti, didapatkan kadar vitamin D serum anak penderita asma umumnya lebih rendah daripada anak normal. Sementara dalam hubungannya dengan fungsi paru, derajat asma, kekerapan gejala maupun fungsi kontrol, bervariasi pada tiap penelitian ${ }^{4}$.

Sementara pada penelitian kami ditunjukkan bahwa kadar vitamin D serum pada penderita asma tidak menunjukkan korelasi yang bermakna dengan derajat kekerapan asma. Namun begitu, hal ini masih dapat dipengaruhi oleh beberapa faktor risiko yang dapat menjadi potensi variabel perancu yang belum diteliti, seperti riwayat alergi dalam keluarga, faktor infeksi saluran napas berulang, paparan polusi maupun faktor lingkungan lainnya yang dapat menjadi penyebab seringnya pasien mengalami serangan asma.

Kelemahan dari penelitian kami adalah penulis tidak dapat menyingkirkan variabel perancu, seperti riwayat alergi dalam keluarga, faktor infeksi saluran napas berulang, paparan polusi maupun faktor lingkungan lainnya yang dapat menjadi penyebab seringnya pasien mengalami serangan asma. Hal tersebut menimbulkan bias yang besar terhadap derajat kekerapan asma pada anak.

\section{Kesimpulan}

Kadar vitamin D plasma yang rendah memiliki korelasi lemah terhadap derajat kekerapan asma yang 
lebih tinggi pada anak. Perlu dilakukan penelitian dengan mempertimbangkan faktor-faktor yang dapat memengaruhi derajat kekerapan asma.

\section{Daftar pustaka}

1. Kemenkes RI. Riset Kesehatan Dasar; RISKESDAS. Jakarta: Badan Penelitian dan Pengembangan Kemenkes RI; 2018.

2. Rahajoe N, Kartasasmita CB, Supriyatno B, Setyanto DB. Pedoman nasional asma Anak. Edisi ke-2. Jakarta: Badan Penerbit Ikatan Dokter Anak Indonesia; 2015.

3. Peroni DG, Trambusti I, Di Cicco ME, Nuzzi G. Vitamin D in pediatric health and disease. 2020. Pediatr Allergy Immunol 2020;31(Suppl 24):54-7.

4. Jat KR, Khairwa A. Vitamin D and asthma in children: A systematic review and meta-analysis of observational studies. Lung India 2017;34:355-63.

5. Akbar N, Zacharek M. Vitamin D: immunomodulation of asthma, allergic rhinitis, and chronic rhinosinusitis. Current Opinion in Otolaryngol Head and Neck Surg 2011; 19:224-8.

6. Ali N S, Nanji K. A Review on the role of vitamin D in asthma. Cureus 2017;9:e1288.

7. Batubara J, Tridjaja B, Pulungan AB. Buku ajar endokrinologi anak. Edisi kedua. Jakarta: Badan Penerbit Ikatan Dokter Anak
Indonesia; 2018.

8. Poh BK, Rohjroongwansikul N, Nguyen BKL, dkk. 25-hydroxy-vitamin D demography and the risk of vitamin D insufficiency in the South East Asian Nutrition Surveys (SEANUTS). 2016. Asia Pac J Clin Nutr 2016;25:538-48.

9. Adams SN, Adgent MA, Gebretsadik T, dkk. Prenatal vitamin D levels and child wheeze and asthma. J Matern Fetal Neonatal Med 2021;34:323-31.

10. Kang Q, Zhang XY, Liu SJ, Huang F. Correlation between the vitamin D levels and asthma attacks in children: Evaluation of the effects of combination therapy of atomization inhalation of budesonide, albuterol and vitamin D supplementation on asthmatic patients. Exp Ther Med 2018;15:727-32.

11. Bener A, Ehlayel MS, Tulic MK, Hamid Q. Vitamin D deficiency as a strong predictor of asthma in children. Int Arch Allergy Immunol 2012;157:168-75.

12. Gupta A, Sjoukes A, Richards D, dkk. Relationship between serum vitamin $\mathrm{D}$, disease severity, and airway remodeling in children with asthma. Am J Respir Crit Care Med 2011;184:1342-9.

13. Brehm JM, Perez, EA, Klei L, dkk. Vitamin D insufficiency and severe asthma exacerbations in Puerto Rican Children. Am J Respir Crit Care Med 2012;186:140-6.

14. Searing, Zhang Y, Murphy JR, dkk. Decreased serum vitamin $\mathrm{D}$ levels in children with asthma are associated with increased corticosteroid use. J Allergy Clin Immunol 2010;125:9951000 . 